\title{
2008 Rusya-Gürcistan Savaşı'nın Uluslararası Hukukta Kuvvet Kullanma Yasağı Çerçevesinde Analizi
}

\author{
Vildan Meydan ${ }^{1}$
}

Öz

Günümüz uluslararası sisteminin oldukça karmaşık yapısı, ulus devletlerin son zamanlarda sıkça yaşamaya başladığı azınlık problemleri ve azalan ulus devlet kavramı, ayrılıkçı hareketleri de beraberinde getirmiştir. Ayrılıkçı hareketler; bulundukları ülkeler içerisinde çatışmalar doğurmuş, bunların bazıları ise başka aktörlerin de müdahil olmasıyla uluslararası bir soruna dönüşmüștür. Bunun bir örneği de Gürcistan'ın Güney Osetya bölgesinde görülen ayrılıkçı hareketlerdir. Osetler daha önce de ayrlık talebinde bulunmuş, son olarak Gürcistan'ın bölgeye müdahale etmesiyle bölgede yaşanan gerginlik çatışmalara dönmüștür. Rusya'nın olaya müdahil olmasıyla beraber 2008 savaşı yaşanmıştır. Savaşın ardından Rusya, Osetya'nın bağımsızlığını tanımış, uluslararası arenada ise bir tepkiyle karşılaşmıştır. Tepkiler Gürcistan toprak bütünlüğünün ihlal edildiği üzerinde yoğunlaşırken Rusya, müdahalesini meşru müdafaa olarak nitelendirmiştir. Rusya'nın meşru müdafaa iddiasının uluslararası hukuka göre meşru bir zemini var mıdır? Bu çalışmanın amacı Rusya'nın Gürcistan ve Osetya müdahalesinin uluslararası hukuka uygunluğunu sorgulamaktır.

Anahtar Kelimeler: Meșru müdafaa, uluslararası hukuk, Rusya, Gürcistan, Güney Osetya

\section{The Analysis Of 2008 Russia-Georgia War In The Context Of The Ban On Use Of Force In The International Law}

\begin{abstract}
The complicated structure of modern international system, minority problems that nation states have faced frequently and the concept of nations state that declining have brought separatist movements. Separatist movements caused to conflicts in mother states, some of them have become international problem with some other actors and states that intervene. An example of that is the separatist movement of Ossetians in the area of Georgia's South Ossetia. Ossetians have demanded autonomy for many times before, in their final demand, Georgian forces intervened the area. With participation of Russia to problem, 2008 Russian- Georgian war broke out. After the war, Russia recognized South Ossetia's independence and have faced reactions in international arena. While Georgia assert that their territorial integrity has been violated by Russia, Russian side describes his intervention as self-defence. Is there a legal basis of Russian side's assertation according to international law? The aim of this study is to examine the suitability of Russian's intervention to Georgia ( and South Ossetia ) to international law.
\end{abstract}

Key Words: Self defense, international law, Russia, Georgia, South Ossetia

\footnotetext{
${ }^{1}$ Arş. Gör., İstanbul Üniversitesi, Siyaset Bilimi ve Uluslararası İlişkiler Bölümü, vildanercan1@gmail.com
} 


\section{Giriş}

Uluslararası hukuk, tıpkı uluslararası ilişkiler disiplini gibi, dünya arenasında yakın bir tarihte yerini almıştır. Tüm dünyayı etkisi altına alan iki dünya savaşının ardından uluslararası arenadaki ilk çaba, evrensel olarak güvenlik ve barışı sağlamaya yönelik olmuştur. Bu amaç doğrultusunda atılan en önemli adımlardan birisi ise, Birleşmiş Milletler tarafından oluşturulan kuvvet kullanma yasağına ilişkin olmuştur. Buna göre Birleşmiş Milletler, 1945 Antlaşması'nın örgütün amaçlarının yer aldığı birinci bölümde, tüm devletlerin uluslararası barışı korumaya yönelik hareket etmesi gerektiğini belirtmiştir ( Birleşmiş Milletler 1945: 4). Hemen devamında ikinci maddenin dördüncü fıkrasında ise kuvvet kullanma yasağını belirtmiştir ( Birleşmiş Milletler 1945: 5). Antlaşmanın diğer bölümlerinde ise kuvvet kullanma yasağından hareketle, ülkelerin toprak bütünlüğüne saygı gösterilmesi gerektiğinden bahsedilmiş, ülkeler uluslararası barış ve güvenliğin oluşturulması yolunda belirli yükümlülüklere tabi tutulmuştur.

Birleşmiş Milletler'in, uluslararası güvenlik ve barıșın sağlanması yönünde aldığı bu önlemlere karşın kuvvet kullanma yasağı, zaman zaman ülkelerce ihlal edilebilmektedir. Kuvvet kullanma yasağı konusunda uluslararası olarak bir birlik sağlanmış olmamakla birlikte, bu kural bazı tartışmalara da yol açmıştır. Tartışmalara yol açan durumlardan birisi olarak ise, Birleşmiş Milletler'in belirli koşulların gerçekleşmesi karşılığında devletlerin uluslararası arenada kuvvet kullanmasına izin vermesi gösterilebilir (Solak 2016: 126). Bu noktadan hareketle, uluslararası hukukta kuvvet kullanma yasağının kapsamı konusunda tartışmalar hala devam etmektedir. Birleşmiş Milletler'in belirli koşullarda kuvvet kullanımına izin vermesi gibi istisnai durumlar, devletlerin gerektiğinde uluslararası eylemlerini haklı çıkartabilecekleri bir ortam oluşturmuştur.
Günümüz uluslararası sisteminin oldukça karmaşık yapısına, son zamanlarda ortaya çıkan farklı bölgelerde sıkça görülmeye başlanan bölgesel çatışmalar da eklenince uluslararası güvenlik ve barışın tehlikeye girebileceği ve bu bölgesel çatışmaların küresele dönüşebileceği riskinin oldukça yüksek olduğunu söylemek yanlıș olmayacaktır. Uluslararası sistemde ülkelerin farklı sayıda etnik topluluklara ev sahipliği yapmaları, bu etnik toplulukların bazılarının ayrılıkçı hareketleriyle karşı karşıya kalmalarına sebep olmuştur. Bu sorunla karşı karşıya kalan ülkelerden birisi de Gürcistan'dır. Gürcistan'ın Güney Osetya bölgesinin özerklik talebi çatışmalara yol açmış, bir süre sonra Rusya'nın olaya müdahil olmasıyla çatışmalar devam etmiştir. Rusya'nın Gürcistan'a müdahale etmesi, 2008 Rusya-Gürcistan Savaşı'nı beraberinde getirmiştir. Savaşın ardından Gürcistan, ülke bütünlüğüne saldırı yapıldığını belirtmiş, buna karşılık Rusya ise eylemini meşru müdafaa hakkı çerçevesinde savunmuştur. Rusya'nın Gürcistan'a müdahalesi uluslararası hukuk kapsamında meşru mudur? Diğer bir deyișle Rusya'nın meşru müdafaa hakkını kullanması uluslararası hukuka uygun mudur? Dolayısıyla çalışmanın amacı; gerektiğinde ülkelerin uluslararası hukuk kurallarını nasıl amaçlarına göre yorumladıklarını, meşru olmayan eylemlerini nasıl meşru bir zemine oturttuklarını göstermektir. Buradan hareketle çalışmada Rusya'nın Gürcistan müdahalesinin uluslararası hukuktaki yerini bulmak ve meşru müdafaa hakkının uluslararası hukuka göre hangi durumlarda meşru olduğunu daha net hatlarıyla göstermek amaçlanmıştır. 


\section{Uluslararası Hukukta Kuvvet Kullanımı}

\section{Kuvvet Kullanımı Kavramının Tarihi Gelişimi}

Birleşmiş Milletler Kurucu Antlaşması'nın 2/4. Maddesi kapsamında uluslararası hukukta kuvvet kullanımına yasak getirilmiştir:

“Tüm üyeler, uluslararası ilişkilerde gerek herhangi başka bir devletin toprak bütünlüğüne ya da siyasal bağımsızlığına karşı, gerek Birleşmiş Milletler'in amaçları ile bağdaşmayacak herhangi bir biçimde kuvvet kullanma tehdidine ya da kuvvet kullanılmasına başvurmaktan kaçınırlar." (Karadağ 2016: 174)

$\mathrm{Bu}$ maddeden de açıç̧a görüleceği gibi, uluslararası hukuk için devletin toprak bütünlüğüne saygı, temel prensiplerden birisi olmuştur. Aslında kuvvet kullanımına ilişkin kurallar zaman içinde evrim geçirmiştir. Birinci Dünya Savaşı'nı takip eden süreçte savaş, devletler açısından bir hak olarak görülmekte, dolayısıyla kuvvet kullanım yasağı bulunmamaktadır. Bu durum 20. Yüzyıl itibariyle değişiklik göstermiş, teknolojinin gelişimiyle birlikte savaşların tahrip gücünün daha ağır olmaya başlaması ile devletler savaş yerine savaşa varmayan kuvvet kullanma yollarına başvurmayı tercih etmişlerdir. Kuvvet kullanımının düzenlenmesi ise Milletler Cemiyeti döneminde gerçekleşmiştir. Buna göre devletler öncelikle aralarındaki sorunları çözmek için öncelikle barışçıl yolları denemelidir; bu yolların tüketilmesi durumunda savaşa başvurma hakkı olabilecektir ( Keskin 1998: 25-30 ).

Birleşmiş MilletlerAntlaşması'na kadar geçen sürede kuvvete başvurmanın kısıtlanması yönündeki ikinci önemli belge, 1928 BriandKellog Paktı, bir diğer adıyla 'Savaşı Ulusal Politikanın Bir Aracı Olarak Yasaklayan Antlaşma"dır. Pakt, anlaşmazlıkların çözülmesi yolunda savaşa başvurmayı yasaklamış ve anlaşmazlıkların çözümünün kaynağının barışçı yollar olması gerektiğini belirtmiştir. Milletler Cemiyeti Antlaşması'nda kuvvet kullanımı tamamen yasaklanmamış, daha ziyade ülkelerin anlaşmazlık çözümünde barışçıl yollar teşvik edilmiş, bu şekilde kuvvet kullanımının geciktirilmesi amaçlanmıştır. Briand-Kellog Paktı ise kuvvet kullanımını yasaklayan, dolayısıyla da savaşı yasaklayan ilk belge olması sebebiyle önemlidir. Fakat BriandKellog Paktı, Birleşmiş Milletler Kurucu Antlaşması'nın çok küçük bir kısmını oluşturmaktadır. Dolayısıyla uygulanan uluslararası hukukta kuvvet kullanımının kısıtlanmasına dair asıl düzenlemeyi, Birleșmiş Milletler Kurucu Antlașması içermektedir ( Keskin 1998: 34 ).

\section{Uygulanan Uluslararası Hukukta Kuvvet Kullanımı Kavramı}

Birleşmiş Milletler Kurucu Antlaşması, 1945 tarihinde yürürlüğe girmiş olup, örgütün amaçlarının yer aldığı ilk bölümde uluslararası barışın korunmasına değinilmiş, 2/4. Maddesinde ise kuvvet kullanımını kısıtlayan ifade yer almıştır. Dolayısıyla Birleşmiş Milletler'in zorlama yolları ile meşru müdafaa dışındaki bütün kuvvet kullanma yolları Birleşmiş Milletler Antlaşması ile yasaklanmıştır ( Çiftçi 2016: 504). Birleşmiş Milletler Antlaşması, Milletler Cemiyeti ve Briand- Kellog Paktı'nda temelleri atılan kuvvet kullanma yasağının daha genişletilmiş ve kesin hali olarak nitelendirilebilir. Birleşmiş Milletler Antlaşması ayrıca, kuvvet kullanma yasağının yanı sıra kuvvet kullanma tehdidini de yasaklamıştır. Buna göre iç çatışmalar kuvvet kullanma kapsamına girmemektedir. Kuvvet kullanma yasağı, doğrudan silahlı kuvvet kullanılmasının yanı sıra, dolaylı yollarla kuvvet kullanımını da kapsamaktadır.

\section{Kuvvet Kullanma Yasağına İstisna Olușturacak Durumlar}

Yukarıda da belirtildiği gibi Birleşmiş Milletler iki istisnai durum haricinde kuvvet kullanımını doğrudan veya dolaylı olarak yasaklamıştır. Bu istisnai durumlardan birisi meşru müdafaa hakkı iken, diğeri Birleşmiş Milletler Güvenlik Konseyi tarafından yetkilendirilmedir. 


\section{Meșru Müdafaa Hakkı}

Uluslararası hukukta meșru müdafaa hakkı; bir devletin başka bir devletçe kendisine karşı girişilen hukuka aykırı kuvvet kullanma eylemine, ani ve doğal olarak kuvvet kullanma yoluyla karşılık vermesidir. (Pazarcı 2015: 524) Meşru müdafaa hakkına ilişkin, temel olarak iki kaynak bulunmaktadır: örf ve adet hukuku ile Birleşmiş Milletler Antlaşması 51. Maddesi. İki kaynak da meşru müdafaa hakkına farklı açılardan katkı sağlamıştır.

Meşru müdafaa hakkı, Birleşmiş Milletler Antlaşması öncesinde, örf ve adet hukuku içerisinde yer almaktaydı. Örf ve adet hukuku kapsamındaki meşru müdafaa hakkı, Birleşmiş Milletler döneminde ele alınan haline nazaran daha sınırlı olmakla birlikte, büyük oranda Caroline olayına dayanmaktadır. Kanada'da 1837 yılında meydana gelen ayaklanmada İngiliz Kuvvetleri, Kanada'ya yardım sağlayan Amerikan gemisini ele geçirerek yakmıştır. Olay sonrasında İngiltere eylemini meşru müdafaa olarak nitelendirmiş, Amerika da buna karşıllk İngiltere'den eylemlerinin gereklilik ve orantılılık kıstaslarına uygun olduğunu kanıtlamalarını istemiştir. Bunun üzerine örf ve adet hukuku kapsamında meşru müdafaa ortaya çıkmıştır. Bu kapsamdaki meşru müdafaa hakkının koşulları olarak gereklilik ve orantılılık gösterilmiştir. Nitekim Amerika Dışişleri Bakanı Webster, "ani, karşı konulmaz, başka bir araç seçimine ve düşünmeye imkan bırakmayan bir meşru müdafaa zaruretinin olduğunun" kanıtlanması ve "meşru müdafaa zarureti ile haklı görülebilecek bir eylem, bu zaruret [necessity] ile sınırı olmalı ve kesinlikle bu kapsam dahilinde kalmalıdır" sözleri ile meşru müdafaa hakkının koşullarını ortaya koymuştur ( Taşdemir 2006: 80 ). Acillik, orantılıık ve gereklilik koşulları olarak Webster'in ortaya koyduğu bu formül, daha sonra diğer devletlerin meşru müdafaa eylemlerinde de aranmış, böylece örf ve adet hukuku içerisinde kendisine yer bulmuştur.

Birleşmiş Milletler döneminde Meşru müdafaa hakkı, Birleşmiş Milletler Antlaşması'nın “ Barışın Tehdidi, Bozulması ve Saldırı Halinde Yapılacak Hareket" başlıklı 7. bölümünde, 51. Madde ile açıklanmıştır:

“ Bu anlaşmanın hiçbir hükmü, Birleşmiş Milletler üyelerinden birinin silahlı bir saldırıya hedef olması halinde, Güvenlik Konseyi uluslararası barış ve güvenliğin korunması için gerekli önlemleri alıncaya dek, bu üyenin doğal olan bireysel ya da ortak meşru savunma hakkına halel getirmez. Üyelerin bu meşru savunma hakkını kullanırken aldıkları önlemler hemen Güvenlik Konseyi'ne bildirilir ve Konsey'in işbu anlaşma gereğince uluslararası barış ve güvenliğin korunması ya da yeniden kurulması için gerekli göreceği biçimde her an hareket etme yetki ve görevini hiçbir biçimde etkilemez." ( Çiftçi 2016: 504 )

İlgili maddeden de anlaşılacağı üzere Birleşmiş Milletler; meşru müdafaa hakkının gerçekleşebilmesi için bazı şartlar belirtmiştir. Bu şartlardan birisi de devletlerin silahlı saldırıya maruz kalmasıdır. Yani devletler, herhangi bir silahlı saldırı olmadığı durumlarda meşru müdafaaya başvuramaz. Diğer bir şart ise devletlerin meşru müdafaa hakkına başvurdukları takdirde, bu durumun Güvenlik Konseyi'ne bildirilmesidir. Dolayısıyla silahlı bir saldırıya maruz kalan bir devlet, Birleşmiş Milletler Güvenlik Konseyi bir karar alıncaya dek kendisini koruma hakkına sahiptir. Meşru müdafaa hakkının koşulları, gerek 51. Madde kapsamında, gerekse örf ve adet hukuku kapsamında ayrı ayrı ele alınacaktır.

\section{Meșru Müdafaa Hakkının Koșulları}

\section{Silahlı Saldırı}

Bir devletin meşru müdafaa hakkına başvurması için Birleşmiş Milletler'in belirtmiş olduğu en önemli koşul, devletin egemenliğine ve toprak bütünlüğüne yönelik bir silahlı saldırı olmasıdır. Nitekim Birleşmiş Milletler Antlaşması'nda da belirtildiği üzere uluslararası barış ve istikrarın sağlanması yolunda devletlerin egemenliği son derece önem taşımaktadır. Herhangi bir silahlı saldırıya maruz kalan devlet, meşru müdafaa hakkını kullanma imkanına sahip olur. Bu noktada silahlı saldırının tanımını yapmak 
önemlidir. Nitekim bir saldırının silahlı saldırı olarak nitelendirilebilmesi için ne gibi özellikler taşıması gerektiği sorunu ortaya çıkmaktadır. Birleşmiş Milletler Genel Kurulu'nun 1974 tarihli ve 3814 sayılı kararının 3. Maddesi, hangi durumların silahlı saldırı olarak sayılacağı konusunda bilgi vermektedir.

(a) Bir devletin silahlı güçleri tarafından başka bir devletin ülkesine saldırı veya bu ülkenin işgal edilmesi ya da geçici de olsa böyle bir saldırı veya işgalden kaynaklanan askeri işgal veya kuvvet kullanma yoluyla başka bir devlet ülkesinin ya da bir parçasının ilhak edilmesi,

(b) bir devletin silahlı güçlerinin başka bir devletin ülkesini bombardıman etmesi veya bu devlet ülkesine karşı başka herhangi bir silah kullanması,

c) bir devletin silahlı güçlerinin başka bir devletin liman ve kıyılarını ablukaya alması,

(d) bir devletin başka bir devlet kara, deniz veya hava kuvvetlerine veya deniz ve hava filolarına silahlı güç kullanarak saldırması,

(e) bir antlaşma ile başka bir ülkede bulunan silahlı kuvvetlerin, antlaşmada belirtilen şartlara aykırı olarak kullanılması veya antlaşmanın belirlediği süreden daha uzun süre bu ülkede kalması,

(f) devletin kendi ülkesini başka bir devlete saldırı için kullandırması,

(g) başka bir devlete o ülkede silahlı saldırı oluşturabilecek yoğunlukta silahlı güç kullanma olayları gerçekleştiren silahlı kollar, gruplar, düzensiz birlikler veya lejyonerler göndermek. (Çiftçi 2016: 504-505)

Belirtilen bu saldırıların ilk beş türü doğrudan, diğer ikisi ise dolaylı saldırı kapsamına girmektedir. Bu maddeler dışında kalan herhangi bir durum silahlı saldırı olarak nitelendirilemeyeceğinden, devletler meşru müdafaa hakkına başvuramazlar.

\section{Birleșmiş Milletler Güvenlik Konseyi'ne Bilgi Verilmesi}

Topraklarına yönelik herhangi bir silahlı saldırıya maruz kalan devletler, meşru müdafaa hakkına başvurabilme imkânına sahiptir. Fakat devletler meșru müdafaa hakkına başvururken bu durumu Birleșmiş Milletler Güvenlik Konseyi'ne bildirmek zorundadır. Birleşmiş Milletler Güvenlik Konseyi, herhangi bir karar alana dek saldırıya maruz kalan devlet meşru müdafaa hakkına başvurabilir. Devletlerin bu hakkı, Güvenlik Konseyi'nin, uluslararası barışı koruma yolunda herhangi bir adım atması durumunda sona erer. Meşru müdafaa hakkının amacı da zaten Güvenlik Konseyi herhangi bir adım atana kadar geçen sürede silahlı saldırıya karşılık verilmesidir.

\section{Örf ve Adet Hukuku Çerçevesinde Gereklilik ve Orantılılık}

Uluslararası Adalet Divanı 1986 tarihli Nikaragua Davası'nda, meşru müdafaa hakkının, anlaşmalar hukukunun yanı sıra, örf ve adet hukuku kapsamında da ele alınacağını göstermiştir. Nitekim hem 51. Madde hem de örf ve adet hukuku hükümlerini içeren bir karar vermiş, 51.maddede yer almayan gereklilik ve orantıılık koşullarını kabul etmiştir ( Keskin 1998: 54). Nitekim 51. Maddedeki “... doğal olan bireysel ya da ortak meşru savunma hakkı." ifadeleri de Divan'ın kararını doğrulamaktadır. 51 . maddede söz edilmemesine rağmen meşru müdafaa hakkına başvurulabilmesi için gereken şartlardan bir diğeri olarak gereklilik, orantılılık ve acillik gösterilmiştir. Bu noktada sözü edilen gereklilik ile saldırının durdurulması için başka bir olanağın kalmaması, orantılılık ile saldırıyı durduracak ve etkilerini ortadan kaldıracak ölçüde kuvvete başvurulması kastedilmektedir. Orantılıık koşulu saldırıya uğrayan devlete, meşru müdafaa eyleminin silahlı saldırı eylemi ile orantılı şekilde gerçekleştirilmesi yükümlülüğü getirmektedir. Acillik şartı ise, bir devletin meşru müdafaa hakkına başvurabilmesi için tehdidin birden oluşması gerektiğini belirtmektedir. Bu tarz ani bir 
saldırı durumunda saldırıya uğrayan devlet, kendisini savunmak amacıyla meșru müdafaa hakkına başvurabilir.

\section{Birleșmiş Milletler Güvenlik Konseyi Yetkilendirmesi}

Kuvvet kullanımının ikincisi istisnai durumunu, Birleşmiş Milletler Güvenlik Konseyi'nin yetkilendirmesi oluşturmaktadır. Birleşmiş Milletler Kurucu Antlaşması'nın amaçları arasındaki en önemli ve temel madde, uluslararası barıș ve güvenliğin korunmasıdır. Yine aynı antlaşmanın 39, 41 ve 42. Maddeleri ise uluslararası barış ve güvenliğe tehlike arz edecek durumlar için oluşturulmuş olup, kuvvet kullanımının ikinci istisnai durumunun kaynağını oluşturmaktadır. Buna göre Birleşmiş Milletler 39. Madde kapsamında, uluslararası barışın tehlikeye girmesi durumunda tavsiyelerde bulunma ve gerekirse 41 ve 42 . Maddelere başvurma hakkına sahiptir. Uluslararası sistemde barışın tekrar sağlanması amacıyla gerekirse ekonomik ilişkilerin hava deniz ya da kara yoluyla kesintiye uğratıması, diplomatik ilişkilerin kesilmesi gibi yaptırımları içeren 41. Maddenin de etkisiz kaldığı durumlarda Birleşmiş Milletler Güvenlik Konseyi, 42. Maddeye dayanarak hava, deniz ya da kara kuvvetleri aracılığıyla önlemler alabilir. Bu önlemler, gösterileri, ablukayı ve Birleşmiş Milletler üyelerinin hava, deniz ya da kara kuvvetlerince yapılacak başka operasyonları da içerebilir. (Birleşmiş Milletler 1945: 14)

\section{Gürcistan - Rusya Çatışması ve Güney Osetya}

\section{Güney Osetya'nın Tarihi Geçmişi}

Güney Osetya, Kafkas Dağları'nın güneyinde, Gürcistan sınırları içerisinde yer alan ve başkent Tiflis'ten yaklaşık $40 \mathrm{~km}$ uzaklıkta bulunan, 3900 kilometre karelik alana sahip bir bölgedir. Bölgedeki 70.000 - 90.000 arasındaki nüfusun yaklaşık \%70-85'ini Osetler oluştururken, \%10-20 arasını ise Gürcüler oluşturmaktadır ( Bartuzi vd. 2008: 5).
Osetya bölgesi Kuzey Osetya ve Güney Osetya olarak iki kısımdan oluşmaktadır. Kuzey Osetya, şu anda Rusya Federasyonunda özerk bir cumhuriyettir. Daha öncesinde SSCB döneminde ise yine aynı statüye sahipti ( Higgins ve O'Reilly 2009:568). Güney Osetya ise 1801 yilından itibaren Rusya İmparatorluğu'nun parçasıydı. İmparatorluğun yıkılmasının ardından birinci Gürcistan Cumhuriyeti ( 1918-1921) döneminde, Güney Osetya bölgesinde çok sayıda ayaklanmalar yaşanmıştı. 1921 yılında Gürcistan hükümeti devrildi ve aynı yıl Gürcistan, Sovyetler Birliğine bağlı cumhuriyetlerden birisi oldu ( Higgins ve O'Reilly 2009:569). Güney Osetya bu dönemde Gürcistan SSC'ye bağlı otonom bir bölge olarak varlığını sürdürmekteydi ( Hancilar 2011: 113). SSCB'nin 1991 yllında parçalanmasını takiben Gürcistan da bağımsızlığını ilan etti ve böylece Cürcistan sınırları içerisinde otonom bir bölge olan Güney Osetya bu statüsünü kaybetti. Sovyetler Birliğinin dağılmasını takiben, bölgede gerilim tekrar arttı. Gerilimin nedeni ise Osetya'nın otonom bir bölge olmaktan hiçbir zaman memnun olmamasıdır. Dolayısıyla Güney Osetya Sovyetlerin dağılmasıyla otonom statüsünü kaybetmişken, Kuzey Osetya gibi statüsünü özerk bir cumhuriyet durumuna getirmek istemiştir. ( Higgins ve O'Reilly 2009: 568569). Daha öncesinde Güney Osetya 1990 yılına gelindiğinde Tiflis yönetimiyle bağlarını gevşetme talebinde bulunmuştur. Ertesi yıl SSCB'nin parçalanması bu talepleri kuvvetlendirmiş, iki taraf arasında yaşanan çatışmalar Rusya'nın arabuluculuğu ile 1992 Haziran ayında imzalanan ateşkese kadar sürmüştür. ( Hancılar 2011: 113)

1992 Soçi Antlaşması ve hükümleri, sorunun çözümünü sağlamadı, daha ziyade bölge donuk çatışma safhasına girdi. Yani Abhazya, Dağlık Karabağ ve Transdinyester bölgelerinde olduğu gibi, şiddet durmuş, fakat süregiden bir barış sağlanamamıştı ( Higgins ve O'Reilly 2009: 570). ỉki taraf arasında imzalanan ateşkese rağmen Osetya, ayrılıkçı taleplerini sürdürmüştür. Bölgede 1992 ateşkesini takiben 1993-2004 yılları arasında kısa süreli istikrar sağlanmış gibi 
görünse de, Saakaşvili'nin 2003 yılında Gül Devrimi ile iktidara geçmesi, bu gidişatı değiştirmiştir. Saakaşvili yönetime geçtikten sonra, Gürcistan'ı üniter bir yapıya taşımak amacı ile Güney Osetya ve Abhazya'yı kontrol altına almak için çalışmalara başlamıştır. Bu amacı gerçekleştirmek için Saakaşvili, sırtını ABD başta olmak üzere Batıya dayamış, güvenliğin sağlanmasının Nato üyeliği ile mümkün olacağını düşünerek politikalarını bu amaç doğrultusunda oluşturmuştur. Saakaşvili'nin bu adımları, Rusya'nın bölgede etkinliğini iyiden iyiye artırmasına ve Güney Osetya'da çatışmaların tekrar başlamasına neden olmuştur ( Kurt, 2012)

2004 yılında çatışmalar tekrar başlamış ve Rusya statüko yanlısı politikaların hiçbir işe yaramayacağı gerekçesiyle, Güney Osetya ve Abhazya'daki bağımsızlık hareketlerini destekleme kararı almıştır (Ercan 2015:102). Rus hükümetinde bu düşüncenin oluşmasının sebepleri ise Gürcistan'da Batı destekli bir yönetimin başa geçmesi, ABD'nin Kafkasya'ya girerek Rusya'yı ve Hazar enerji havzasını tehdit etmeye başlaması, Nato'nun Doğu Avrupa üzerinden Rusya'yı çevrelemeye başlamasıdır. Nato'nun son olarak bu çevrelemeyi Gürcistan üzerinden yapmaya başlaması üzerine Rusya, Güney Osetya ve Abhazya'daki ayrılıkçı hareketleri şiddetlendirme kararı almıştır. ( Kurt, 2012 )

\section{Ağustos 2008: Rusya - Gürcistan Savașı}

1992 ve 2008 yılları arasında Güney Osetya ve Gürcistan arasındaki gerilim " donuk " bir aşamadaydı. Ne ülke içi mülteci durumundaki insanlar Güney Osetya'daki evlerine dönebilmişti, ne de Gürcistan, Güney Osetya'nın bağımsızlığını tanımıştı (Nußberger 2009: 358). 2008 yılının henüz başlarında bölgede artan gerilim ve yaşanan çatışmalar, iki taraf arasında yaşanacak bir savaşın habercisi niteliğindedir. Nitekim Mayıs ayında Gürcistan'ın Rusya'yı, Gürcistan'a ait bir insansız hava aracını vurmakla suçlaması gerilimleri artırmıştır. Haziran ayında Güney Osetya ve Gürcistan kuvvetleri arasında başkent Şinvali'deki çatışmalarda bir kişi hayatını kaybetmiştir. Bunun yanı sıra polis memurlarının da içinde bulunduğu 8 kişi yaralanmıştır. ( Higgins ve O'Reilly 2009: 571) Bu çatışmaların akabinde Gürcü kuvvetleri Güney Osetya'ya çeşitli saldırılar düzenlemiş, fakat karşısında Rusya'nın karşı saldırılarını bulmuştur. 16 Haziran 2008'de Gürcistan ve Güney Osetya askeri birlikleri arasında yaşanan çatışmada 1 kişi ölmüş, 4 kişi ise yaralanmıştır. ( Cornell vd. 2008: 10)

2008 savaşını asıl başlatan olay ise Gürcü kuvvetlerinin Güney Osetya'nın bașkenti olan Şinvali'ye kapsamlı bir hava ve kara saldırısı düzenlemesiydi. Öyle ki Gürcistan neredeyse Şinvali'yi ele geçirmek üzereydi. Gürcü kuvvetlerinin Şinvali saldırısına Rus birlikleri anında karşılık vermiş, akabinde ise savaş patlak vermiştir. Rusya, Güney Osetya'ya Kuzey Osetya üzerinden birlikler göndererek Gürcü hedeflerini bombalamıştır. (Higgins ve O’Reilly 2009: 571) Savaş sırasında Tiflis yetkilileri, 20.000'den fazla Rus birliğinin Rusya üzerinde sadece Güney Osetya'ya değil, aynı zamanda Abhazya'ya da kara ve deniz yolu ile girdiğini belirtmiştir. Binlerce Rus, Abhazya'da konuşlanmış, Batı Gürcistan'a girmek için idari sınırı geçmiştir. Askeri üsleri işgal etmiş ve sistematik olarak altyapıyı imha etmiştir. Savaşın ilk gününde Gürcülere göre hava sahası 22 defa ihlal edilmiştir. En önemlisi ise Rus birlikleri, başkent Tiflis ve ülkenin batısını birbirine bağlayan hayati önemdeki bir demiryolu köprüsünü havaya uçurmuştur. Bu durum gerçekte Gürcistan'ı ikiye bölmek ve ekonomisini bozmak anlamına gelmektedir. ( International Crisis Group 2008: 3)

Batı dünyasından ise savaş sırasında, sivil altyapılar nedeniyle oluşabilecek insani kriz konusunda endişeler dile getirilmiştir. Çünkü bu konuda hem Rus tarafından hem de Güney Osetya birlikleri tarafından gerçekleştirilen yağmalamalar da söz konusudur. Çatışma bölgesinde yaşayan Gürcü kesimin evleri yakılmış, insanlar herhangi bir yardım ve koruma olmadan zor şartlarda bırakılmıştır. Ayrıca gözlemciler, Güney Osetya askeri personellerinin, Şinvali bölgesindeki Gürcülere ait konutları yağmaladıktan sonra köyleri ateşe verdiklerini de gözlemlemiştir ( Human Rights Watch, 2008). Çatışmanın oldukça 
tahrip edici olduğu, rakamlardan da anlaşlabilmektedir. 19 Ağustos'ta Gürcistan yetkilileri, Gürcü tarafından 146'sı askeri personel, 69'u sivil olmak üzere 215 kişinin öldüğünü, 1,500 civarında kişinin yaralandığını ve 70 askerin kayıp olduğunu belirtti. Rusya ise 64 kişinin öldüğünü ve 323 yaralı olduğunu iddia etti (International Crisis Group 2008: 3). Savaş ayrıca iki taraftan da binlerce insanın yer değiştirmesine sebep olmuştur. Birleşmiş Milletler Mülteciler Yüksek Komiserliği'nin raporuna göre; 35.000 Güney Osetyalı, 85.000 Gürcü, bulundukları yeri terk etmek zorunda kalmıştır. (International Crisis Group 2008: 3)

Saldırıların ardından Gürcistan ordusu Rus kuvvetleri tarafından yenilgiye uğratılmış, Gürcistan, Güney Osetya ve Abhazya'dan çekilmek zorunda kalmış, ayrıca toprakları Rusya tarafından işgal edilmiştir.

\section{Savaş Sonrası iki Tarafın iddiaları ve Uluslararası Tepkiler}

Savaş sonrası her iki taraf da eylemlerini kendi açılarından savunmuşlardır. Gürcü yetkililer; Gürcistan'a ait askeri birliğin, eylemlerini Güney Osetya'daki anayasal düzeni eski haline getirmek amacıyla yaptığını belirtmiştir. (International Crisis Group 2008: 1) Öte yandan Rusya Başbakanı Vladimir Putin ise, Güney Osetya ve Rus tarafına yönelik Gürcistan tarafından soykırım suçu işlendiğini, Gürcü saldırılarından dolayı 1,500-2,000 arası kayıp verildiğini belirtmiş, bundan dolayı da Rusya'nın Güney Osetya insanını koruma sorumluluğu olduğunu ima etmiştir. Rus tarafının iddiaları aynı zamanda Gürcistan'ın savaş suçları işlediği ve etnik temizlik yaptığını da kapsamaktadır ( Higgins ve O’Reilly 2009: 572). Rus yetkililerin savunmalarından da anlaşılacağı üzere Rusya, bölgeye müdahalesini gerek Güney Osetya halkı, gerek bölgedeki Rus halkı korumak için yaptığını belirtmiş, neden olarak ise Gürcistan tarafının savaş suçlarını işaret etmişlerdir.
Rus hükümetinin Gürcistan'a askeri müdahalesini meşrulaştırmak amacıyla yaptığı savunmalar genel olarak şu konuları içermekteydi: Gürcistan'ın Güney Osetya'ya saldırılarını durdurmak, Gürcistan tarafından işlenen savaş suçlarına, soykırım eylemlerine son vermek, bölgedeki Rus halkını korumak, 1992 Antlaşması uyarınca Güney Osetya'yı savunmak. ( Cassese, 2008 ). Ayrıca Rusya Gürcistan'ın yalnızca Güney Osetya'ya karşı illegal bir savaş başlatmadığını, aynı zamanda temel insan haklarını ihlal ettiğini ihlal ettiğini iddia ederken Gürcistan tarafı, ülkesinin toprağını savunurken uluslararası hukuka uygun davrandığını belirtmiştir. ( NuBberger 2009: 345)

Rusya'nın, Gürcistan'a müdahalesine ilişkin hukuki gerekçesi meşru müdafaa hakkı çerçevesinde olmuştur. Rusya Birleşmiş Milletler Güvenlik Konseyi'ne 11 Ağustos 2008 tarihinde bir mektup göndermiş, ( United Nations 2008: 1 ) mektupta ise Gürcistan ordusunun, başkent Şinvali'de 1,500 civarında sivili öldürdüğü ve bunun büyük kısmının Rus vatandaşı olduğu, Rus birliklerine saldırıldığı ve yaralılar bulunduğunu belirtmiştir. Tüm bunların Gürcistan'ın saldırgan tutumunu sergilediğini ve Gürcistan'ın Rus tarafına karşı hukuka aykırı askeri güç kullandığını iddia etmiştir. Mektubun devamında Rusya, bu eylemlerin sonucunda Birleşmiş Milletler Antlaşması'nın 51. Maddesinde belirtilen meşru müdafaa hakkını kullanacağını belirtmiştir.

Ancak bölgeye yapılan ziyaretlerde Rus iddialarının çok da doğru olmadığı gözlemlenmiştir. Rus yetkililerin soykırım suçu ile ilgili iddialarının gerçek olmadığı, bölgede yapılan incelemelerden sonra anlaşılmıştır. Başkent Şinvali'deki hastane, muharip ve siviller de dahil olmak üzere savaşın ilk günlerinde 40 ölü bilgisi verilmiştir (Çakmak 2009: 57). Rusya tarafının iddialarında yer alan ölü ve yaralı sayılarının doğru olmadığını gösteren diğer bir kaynak da bağımsız insan hakları örgütlerinin, yaralı sayısının yüzler civarında olduğunu belirten raporlarıdır. Nitekim Rusya'nın iddia ettiği 2,000'e yakın ölü bilgisi doğrulanamamıștır. Bağımsız insan hakları örgütleri ise hastanelerde onlarla ifade edilebilecek 
sayıda yaralı olduğunu belirtmiştir. (De Waal, 2008) Rusya'nın, Gürcistan'ın bölgedeki eylemlerini durdurmak amacıyla bölgeye müdahale ettiği savunması da haklı değildir. Gürcistan, toprakları içerisinde bulunan Güney Osetya'ya, düzeni sağlamak amacıyla müdahale etme hakkına sahiptir.

Görüldüğü gibi bağımsız insan hakları örgütlerinin aksini gösteren bilgilerine rağmen Rusya, savaştaki ölü ve yaralı bilgisini ısrarla daha yüksek sayıda göstermiştir. Bunun nedeni ise Rusya'nın, bölgeye müdahalesindeki kuvvet kullanımını meşru göstermek, bir diğer deyişle Güney Osetya'yı Kosova örneği ile bağdaştırmak amacında olmasıdır.

Rusya'nın Gürcistan müdahalesi, çoğu Batılı hükümet tarafından hukuka aykırı olarak nitelendirilmiştir. İngiltere Dışişleri Bakanı Miliband, Rusya'nın eylemlerinin barışı korumayı aştığını belirtmiş, hemen ardından Rusya'nın Gürcistan müdahalesini Kosova'dan ayırmıştır. Nato'nun Kosova müdahalesinin, Avrupa'da íkinci Dünya Savaşı'ndan beri görülmemiş derecede bir etnik temizlik ve sistematik insan hakları ihlallerinin sonucunda gerçekleştiğini belirtmiştir. Nato bölgeye müdahale edene kadar Güvenlik Konseyi'nin sorunun barışçıl yollarla çözümü için uğraştığını, fakat Rusya'nın Gürcistan müdahalesinde ise bu unsurların bulunmadığını belirtmiștir. (Hafkin 2010: 227)

Sonuç olarak hem Gürcistan hem Rusya tarafından savaş sırasında çeșitli savaş suçları işlenmişse de, bunlar Rusya'nın iddia ettiği gibi soykırım, etnik temizlik gibi büyük nitelikte suçlar değildir. Nitekim İnsan Hakları İzleme Komitesi'nin raporuna göre Rusya, kasıtlı olarak sivil araçlardaki sivilleri hedef aldığı için suçlu iken, Gürcistan ise sivil ve askeri araçları ayırt etmedeki başarısızlığı ve araçlarıyla çatışmadan kaçan sivil Osetyalılara saldırması sebebiyle suçludur( Buchanan 2009: 6-8).

\section{Rusya'nın \\ Gürcistan \\ Müdahalesinin

Uluslararası Hukuk Açısından Değerlendirilmesi}

Öncelikle belirtmek gerekir ki, Gürcistan'a ait askeri birliklerin, Güney Osetya'ya girerek bölgede anayasal düzeni tekrar sağlamaya çalışması uluslararası hukuka göre başka bir devlete müdahale kapsamına girmemektedir. Çünkü Güney Osetya, Gürcistan'ın bir parçasıdır ve savaşın yaşandığı zamana kadar yaptığı bağımsızlık ilanı uluslararası olarak tanınmamıştır.

Öte yandan Rusya'nın Gürcistan müdahalesi uluslararası hukuka aykırıdır ve iddia edilen meşru müdafaa hakkının geçerli bir zemini bulunmamaktadır. Nitekim Rusya- Gürcistan savaşı, uluslararası hukukta kuvvet kullanma konusunun yeniden tartışılmasına yol açtı. illk tartışma taraflardan hangisinin daha önce diğerine karşı kuvvet kullandığına dair oldu. Gürcistan'ın Güney Osetya'ya askeri müdahalesi belirtilen raporlara göre bazı insan hakları ihlalleri içerse bile, Rusya'nın herhangi bir Birleşmiş Milletler kararı olmadan Gürcistan'a karşı kuvvet kullanması bir uluslararası hukuk ihlali idi. ( Erkan 2016: 33) Nitekim daha önceki bölümde bahsedildiği gibi uluslararası hukukta kuvvet kullanımının iki istisnai durumu bulunmaktadır. Buna göre Birleşmiş Milletler Antlaşması 51. Maddede belirtildiği üzere bir devletin başka bir devlete kuvvet kullanmasının iki istisnai durumunun birisi meşru müdafaa hakkı, diğeri ise, Birleşmiş Milletler Güvenlik Konseyi'nin kararıdır. Bir eylemin meşru müdafaa sayılması için ise, silahlı bir saldırının varlığı gerekmektedir. Rusya'nın Gürcistan müdahalesi, meşru müdafaa hakkı kapsamına girmez. Çünkü Gürcistan'ın Rusya'ya karşı bir silahlı saldırı durumu söz konusu değildir. Gürcistan, ülke toprakları içerisinde yer alan Güney Osetya'da anayasal düzeni sağlamak amacıyla bölgeye girmiştir ve bu, Gürcistan'ın hakkıdır. Eğer Gürcistan, Rusya topraklarını hedef alan bir silahlı saldırı gerçekleştirmiş olsaydı, Rusya'nın meşru müdafaa hakkından söz edilebilirdi. Güney Osetya konusunda ise Rusya'ya yönelik herhangi bir silahlı saldırı durumu bulunmamaktadır. Meşru müdafaa hakkının bir diğer koşulu, Birleşmiş Milletler 
Güvenlik Konseyi'ne bilgi verilmesidir. Fakat Rusya, Güney Osetya'ya müdahale ederken Güvenlik Konseyi'ne herhangi bir bilgilendirmede bulunmamıştır. Meşru müdafaa hakkının gereklilik ve orantıllık koşulu da göz ardı edilmiştir. Nitekim Rusya'nın bölgeye müdahale etmesi için gerekli olan bir durum bulunmamaktadır. Sorunun çözümü için başvurulacak başka yollar denenmemiştir. Ayrıca gerek Rusya'nın gerekse Güney Osetya'nın askeri birliklerinin, Şinvali'deki Gürcü köylerini kasıtlı olarak hedef alması, yakması ve yağmalaması da orantılılık koşulunun ihlal edildiğini göstermektedir. Buradan hareketle meşru müdafaa hakkının koşullarının göz ardı edildiği görülmektedir. Kuvvet kullanma yasağının diğer istisnai durumunu oluşturan Birleșmiş Milletler Güvenlik Konseyi kararı da aynı şekilde Rusya'nın Gürcistan müdahalesinde söz konusu değildir. Bu noktalardan hareket edildiğinde, Rusya'nın meşru müdafaa hakkının hukuki bir zemini yoktur ve Rusya, kuvvet kullanımı yasağını delerek, uluslararası hukuk kurallarını ihlal etmiştir.

Rusya'nın Gürcistan müdahalesini meşrulaştırmak için öne sürdüğü gerekçelere en önemli cevap ise, bölgeye askeri müdahale yetkisi veren herhangi bir Birleșmiş Milletler Güvenlik Konseyi kararı bulunmamasıdır. Bunun dışında Rusya'nın meşru müdafaa hakkından sonra kullandığı en büyük gerekçesinden biri ise, Güney Osetya halkını ve bölgede bulunan Rus vatandaşlarını korumaktır. Rusya'nın bu gerekçesi, uluslararası hukuk için çelişkiler içermektedir. Nitekim Shaw'a göre (2003:44), bir devletin, ülkesi dışında yaşayan vatandaşlarını koruması 19. Yüzyılda yasal olarak görülse de, bu görüş günümüzde söz konusu devletin toprak bütünlüğü ve siyasal bağımsızlığının ihlali söz konusu olduğundan o kadar açık değildir. Ayrıca Malanczuk, (1997: 315) günümüzde çoğu devletin, ülkesi dışında yaşayan halkın korunmasının, müdahalenin gerçekleşeceği ülkenin rızasını gerektirdiği konusunda hemfikir olduğunu belirtir. Yine Shaw (2003: 1024) bu konuda, bir devletin, ülkesi dışında yaşayan halkını koruma hakkının olması için gerekli koşulları şöyle belirtmiştir: “anlık, baskın, başka bir yol bırakmayan ve üzerinde düşünecek vakit olmayan bir meșru müdafaa halinin gerekliliği”. Ve "eylem, meşru müdafaanın gerektiği durumla sınırlı kalmalıdır." Shaw'ın bu ifadelerinden, meşru müdafaanın gereklilik ve orantılılık koşullarını kastettiği açıkça görülmektedir. Başka bir ifade ile bir devletin, kendi ülkesi dışındaki halkını koruma hakkını öne sürebilmesi için : (1) halkına yönelik olası bir zararın olması, (2) halkının bulunduğu ülkenin halkı koruyamaması, (3) koruma tedbirleri, kati suretle zarar görebilecek halkın korunması ile sınırlı olmalıdır. ( Dinstein 2005: 231)

Güney Osetya halkının yaklaşık \%80'inin Rusya pasaportuna sahip olduğu göz önüne alındığında, Rusya, bölgedeki Osetya ve Rus halkını koruma hakkı bulunduğunu ve dolayısıyla bölgeye müdahalesini meşru müdafaa hakkına dayandırdığını belirterek kendi açısından yeterli bir argüman sunmuş olabilir. Fakat Rusya'nın bu iddiaları, meşru müdafaa hakkının kullanılması için oldukça zayıf olduğu gerçeğini değiştirmiyor. Zira Rusya'nın belirttiği gibi, Gürcistan'ın bölgede hem Osetyalılara hem Rus halkına soykırıma varacak derecede bir eylemde bulunduğu kanıtlanamamıştır. Bölgedeki Rus vatandaşlarının iddia edildiği şekilde bir zarar verilmesi durumuyla karşı karşıya kaldığı belirsiz iken, Rus tarafının iddia ettiği soykırım niteliğinde bir eylemin yokluğu kesindir. ( Higgins ve O’Reilly 2009: 581). Bunun yanında Cassese (2008) Rusya'nın, bölge halkına tek taraflı olarak pasaport dağıttığını belirtmiştir. Ayrıca Rusya'nın bölgedeki eylemleri, meşru müdafaa halinin gerekliliği ile sınırlı değildir. Daha önce de belirtildiği gibi Rusya bölgeye müdahalesi sırasında, ülke dışında yaşayan halkları koruma hakkının temel koşullarından olan orantılılık ilkesini ihlal etmiştir. Nitekim 20.000'den fazla Rus birliğinin Rusya üzerinde sadece Güney Osetya'ya değil, aynı zamanda Abhazya'ya da kara ve deniz yolu ile girdiği, çok sayıda Rus askerinin Batı Gürcistan'a girmek için idari sınırı geçtiğini, askeri üsleri işgal ettiğini ve sistematik olarak altyapıyı imha ettiği raporlarda belirtilmiştir. ( International Crisis Group 2008: 3). Buna ek 
olarak Gürcü deniz birliklerinin batırılması ve Güney Osetya dışında Gürcistan içerisindeki bir bölgede yer alan demiryolu köprüsünün bombalanması açıkça orantılılık kuralının ihlalidir ve ülke dışında yaşayan halkların korunması gerekçesiyle meşrulaştırılamaz (Higgins ve O’Reilly 2009: 581).

Tüm bu bilgilerden hareketle, Rusya'nın Gürcistan müdahalesinde meşru müdafaa hakkı ve kuvvet kullanma yasağı çerçevesinde uluslararası hukuku ihlal ettiği açıkça görülmektedir. Bunun dışında bölgeye müdahalesini haklı çıkarmak için öne sürdüğü soykırım, etnik temizlik gibi Gürcistan'a yöneltilen suçlamaları da herhangi bir kanittan yoksundur. Dolayısıyla Rusya, Gürcistan müdahalesinde meşru kuvvet kullanımını gerektirecek iki istisnai durumu da sağlamaması sebebiyle açıkça uluslararası hukuka karşı gelmiştir. Ayrıca meşru müdafaa hakkının koşulları olan silahlı saldırının varlığı, Birleşmiş Milletler Güvenlik Konseyi'nin bilgilendirilmesi, gereklilik ve orantılılık göz ardı edilmiştir. Gürcistan'ın anayasal birliği sağlamak üzere bölgeye müdahale etmesi, en doğal hakkıdır. Çünkü Güney Osetya, savaşın başlamak üzere olduğu dönemde Gürcistan'ın parçasıdır. Buradan hareketle Rusya'nın bölgeye müdahalesi, Gürcistan'ın toprak bütünlüğü ve devletin egemenliği ilkesine aykırıdır. Bu noktadan bakıldığı zaman sadece kuvvet kullanma yasağı ve meşru müdafaa hakkı kapsamında değil, aynı zamanda devletin egemenliği ve toprak bütünlüğüne saygı ilkesine de uygun davranılmamıştır. Daha önce de belirtildiği gibi ülke dışında yaşayan halkın korunması için, müdahalenin gerçekleşeceği ülkenin rızası gerekmektedir. 19. Yüzyılda Rusya'nın gerekçesi yasal olarak görülse de günümüzde devletin egemenliği ilkesi ile ters düşebileceğinden, devletin rızası önemli bir koşuldur. Fakat Rusya'nın Gürcistan müdahalesinde bu açıdan da bir ihlal söz konusudur. Rusya, Gürcistan'ın toprak bütünlüğüne saygı göstermemiş, egemenliğini ihlal etmiştir.

\section{Sonuç}

Sonuç olarak her ne kadar Milletler Cemiyeti'nden bu yana ülkelerin kuvvet kullanmalarına yönelik kısıtlamaların günümüz uluslararası sistemi doğrultusunda düzenlendiği ve iyileștirdiği görülse de, devletlerin hala kuvvet kullanma yasağı ve meşru müdafaa hakkını kendi çıkarları doğrultusunda, gerçekleştirdikleri bazı eylemleri meşrulaştırmak için kullandıkları çıkarımını yapmak yanlış olmayacaktır. Kuvvet kullanımı günümüzde iki istisnai durumla kısıtlanmış olsa da, bazen bu iki istisnanın da karşılanmadığı görülmektedir. Rusya da Gürcistan müdahalesinde kuvvet kullanımının istisnalarını sağlayamamıştır. Rusya, Kafkaslardaki çıkarları doğrultusunda bölgede etkinliğini koruma amacına paralel olarak zaman zaman müdahalelerde bulunmuş, bu müdahalelerinde uluslararası hukuku ihlal etmiştir. Güney Osetya müdahalesinde ise, meşru müdafaa hakkını öne sürmüştür. Yapılan incelemeler ve edinilen bilgiler doğrultusunda, Rusya'nın, Gürcistan'ın Güney Osetya bölgesine gerçekleştirdiği müdahalede uluslararası hukuku, kuvvet kullanma yasağını, meşru müdafaa hakkını, meşru müdafaa hakkının gereklilik, orantılılık, silahlı bir saldırının varlığı ve Güvenlik Konseyi'nin bilgilendirilmesi koşullarını, Gürcistan'ın toprak bütünlüğü ve egemenliğini çeşitli yönleriyle ihlal ettiği sonucuna varılmıştır. 


\section{Kaynakça}

Bartuzi, Wojciech, Petcynzka-Natecz, Katarzyna and Strachota, Krzysztof (2008), " Abkhazia, South Ossetia, Nagorno Karabakh: Unfrozen Conflicts between Russia and the West", Centre for Eastern Studies (CES), Warsaw

“Birleşmiş Milletler Antlaşması”, 1945. https://www.tbmm.gov.tr/komisyon/insanha klari/pdf01/3-30.pdf [ Erişim Tarihi 25 Ağustos 2017]

Buchanan, Jane (2009). Up in Flames: Humanitarian Law Violations and Civilian Victims in the Conflict over Souh Ossetia, New York: Human Rights Watch

Cassese, Antonio ( 2008). "The Wolf That Ate Georgia" , The Guardian, https://www.theguardian.com/commentisfree 2008/sep/01/georgia.russia1 , [ Erişim Tarihi: 11.10.2017]

Cornell, E. Svante, Pojanevski, Johanna and Nilsson, Niklas, (2008), Russis's War in Georgia: Causes and Implications for Georgia and the World, Policy Paper, Central Asia Caucasus Institute Silk Road Studies Program, Washington: John Hopkins University

Çakmak, Cenap (2009). “ Rusya'nın Güney Osetya Politikası, Neo-Self Determinasyon ve UCM'nin Rolü", Bilge Strateji, 1(1): 71-100

Çiftçi, Selda (2016). “ Uluslararası Hukukta Kuvvet Kullanma Yasağı”, Genç Hukukçular Hukuk Okumaları Birikimler-V-, İstanbul: 491511

De Waal, Thomas (2008). "South Ossetia: moral battle lines drawn", Institute for War \& Peace Reporting, https://iwpr.net/globalvoices/south-ossetia-moral-battle-linesdrawn, [Erişim Tarihi: 10 Ağustos 2017]

Dinstein, Yoram (2005). War, Aggression and Self-Defence, 4th Edition, Cambridge: Cambridge University Press
Ercan, Murat (2015). "Uluslararası Hukuk Normları Bağlamında Kırım Meselesi: Self Determinasyon Mu? Illhak Mı?" The Journal Academic Social Science Studies, No: 36 : 95113

Erkan, Süleyman (2016). "2008 RusyaGürcistan Savaşı ve Uluslararası Toplum”, International Journal of Economic and Administrative Studies, No:17 : 42-64

Hafkin, Gregory (2010). "The Russo-Georgian War of 2008: Developing The Law of Unauthorized Humanitarian Intervention After Kosovo", Boston University International Law Journal, 28(1): 219-240

Hancılar, Özhan (2011)“Uluslararası Hukukta İnsani Müdahale”, Çankaya University Journal of Law, 7(2): 97-124

Higgins, Noelle and O’Reilly, Kieran.(2009) “ The Use of Force, Wars of National Liberation and the Right to SelfDetermination in the South Ossetian Conflict", International Criminal Law Review, 9(3): 567-583

Human Rights Watch (2008)."Georgian villages in South Ossetia burnt, looted, https://www.hrw.org/news/2008/08/12/geor gian-villages-south-ossetia-burnt-looted, [Erişim Tarihi: 15 Ağustos 2017]

International Crisis Group (2008). "Russia vs. Georgia: The Fallout”, Europe Report No. 195

Karadağ, Ulaș (2016). “ Birleşmiş Milletler Antlaşması'na Göre Meşru Müdafaa Hakkı”, İnönü Üniversitesi Hukuk Fakültesi Dergisi, 7(2) : 171-186

Keskin, Funda (1998).Uluslararası Hukukta Kuvvet Kullanma: Savaş, Karışma ve Birleşmiş Milletler, Mülkiyeliler Birliği Vakfı Yayınları, No: 20, Ankara

Kurt, Emre (2012) “ Dış Politikada Kriz Yönetimi: 2008 Rusya-Gürcistan Savaşı Örneği”, Akademik Perspektif, http://akademikperspektif.com/2012/02/15/dis -politikada-kriz-yonetimi-2008-rusyagurcistan-savasi-ornegi/[SSon Erişim Tarihi: 10 Haziran 2017] 
Malanczuk, Pater (1997). Akehurst's Modern Introduction to International Law, 7th Revised Edition, UK: Routledge

Nichol, Jim (2009). " Russia-Georgia Conflict in August 2008: Context and Implications for U.S. Interests" Congressional Research Service

NuBberger, Angelika (2009). "The War between Russia and Georgia-Consequences and Unresolved Questions", Göttingen Journal of International Law, 1(2): 341-364

Pazarcı, Hüseyin (2015), Uluslararası Hukuk, 14. Bası, Ankara: Turhan Kitabevi

Shaw, Malcolm N. (2003), International Law, 5th Edition, Cambridge: Cambridge University Press

Solak, Hacer (2016). "Rusya'nın Suriye Müdahalesinin Uluslararası Hukukta Kuvvet Kullanımı ve Müşterek Meşru Müdafaa Prensipleri Açısından Analizi”, V. Türkiye Lisansüstü Çalışmaları Kongresi- Bildiriler Kitabı II,

Taşdemir, Fatma (2006). “ Uluslararası Anarşiye Giden Yol: Uluslararası Hukuk Açısından Önleyici Meşru Müdafaa Hakkı", Uluslararası Hukuk ve Politika Dergisi, 2(5): 7589

United Nation Security Council, "Security Council Report" ,S/2008/545, http://www.securitycouncilreport.org/atf/cf/ $\% 7 B 65 B F C F 9 B-6 D 27-4$ EgC-8CD3CF6E4FF96FF9\%7D/Georgia\%20S\%202008\%20 545.pdf, [Erişim Tarihi: 15 Ağustos 2017] 